\title{
A Study on the Effect of Selected Yogic Training Programme on Pittsburgh Insomnia Rating Scale Hindi Version of Female Judo Players
}

\author{
Dhananjoy Shaw ${ }^{1 *}$ and Ranjit Kaur ${ }^{2}$ \\ ${ }^{1}$ Officiating Principal, IGIPESS (University of Delhi), India \\ ${ }^{2}$ Department of physical Education and Sports Sciences, University of Delhi, India
}

Submission: June 12, 2017; Published: October 25, 2017

*Corresponding author: Dhananjoy Shaw, Officiating Principal, IGIPESS (University of Delhi) B-Block, Vikaspuri, New Delhi-110018, India, Email: dhananjoyshaw@gmail.com

\section{Abstract}

Objectives of the study were (1) To determine insomnia rating scale after normal training (not very high intensity or volume) for duration of one month till the competition of female judo players' age ranging from 17 to 23 years (2). To find out the effect of yogic training program on insomnia rating scale just two or three days before the competition of female judo players' age ranging from 17 to 23 years. The study was delimited to sixty female judo players' age ranging from 17 to 23 years. Sleep quality index will be studied using Pittsburgh Insomnia Rating Scale Hindi translation/adaptation i.e. PIRS-Hindi.

Keeping in view the purpose of the study, a large number of female judo players were randomly selected $(\mathrm{N}=60)$ equally divided into experimental group and control group. The corresponding experimental and control group were homogeneous/matched groups in regard to age and sex. The experimental groups were treated with yogic training programme for 30 to 45 minutes progressively, for six days per week, for six weeks, whereas the control groups were not given any treatment. The selected variables were distress score (DS), sleep parameter (SP), quality of life (QL) and total score (TOT).

\section{Conclusions:}

a. Experimental group and control group were not significantly different in pretest in regard to selected variables of insomnia rating scale hence considered as homogeneous group for experimentation.

b. There was negative effect of judo competition on insomnia rating scale (just two or three days) before the judo competition.

c. There was significant difference between the experimental group (trained with selected yogic training programme) and control group (not trained with selected yogic training programme) just two or three days before the competition in regard to selected variables of insomnia rating scale.

d. There was significant positive effect of yogic training programme on insomnia rating scale just two or three days before the competition of female judo players age ranged from 17 to 23 years.

Keywords: PIRS; Sleep parameter; Distress score; Quality of life

\section{Introduction}

Yoga is derived from "Yuj", in verb form which means to unite or to join. Yoga in its noun form and means union. It is concerned with the union of the individual source with the absolute or divine soul. It is a science of development of man's consciousness. Yoga is the "unification of Atma with Parmatma".
It also means the unification of physical, mental, intellectual and spiritual aspects of human being [1].

Pranayama is the regulation of breath or control of prana that is the stoppage of inhalation and exhalation, which Pranayama is the controlled process of breathing or regulation of breath/ 
energy. It means the appropriate control over inhalation and exhalation. Basically there are three constituents of pranayama i.e. puraka (inhalation), kumbhak (retaining the breath) and rechaka (exhalation). There are various types of Pranayamas such as ujjai, anuloma viloma, suryabhedi, sheetkari, sheetali, bhastrika, bhramri, murchha and plavini. It has been proved that pranayama is a very important way for preventing and curin many problems. Pranayama brings several physiological changes in the body. The science of pranayama helps in reducing the respiratory and heart rate, while increasing the quantum of oxygen drawn in and decreasing the outflow of breath. This can be as minimal as two or three cycles per minute. When the respiratory rate goes down then metabolic rate of the body also decreases. The problem of allergic rhinitis, low and high blood pressure, sinusitis, recurrent infections of the upper respiratory tract, vasomotor rhinitis, chronic headaches, migraine, peptic ulcers and anxiety states can all be treated by practice of many kinds of pranayama [2].

There are different types of pranayama namely Suryabhedi, Anulom-Viloma, Ujjayi, Sitkari, Sitali, Bhastrika, Bhramari, etc. we secteled Anulom Vilom Pranayama Inhalation called puraka, retention called kumbhaka and exhalation called rechaka is used in the pranayama. Anulom Vilom pranayama can be practiced with kumbhak or without kumbhaka means holding of the breath. In Anulom Vilom pranayama, breathing is done through one nostril then it is alternated. During anulom vilom pranayama right nostril is close with thumb and the the left nostril is close with ring finger [3].

It has been proved through reviews that pranayama is an important mean for preventing and curing of many diseases. Pranayama brings about several physiological changes in the body. The pranayama helps in reducing the respiratory and heart rate, while increasing the volume of oxygen in and decreasing the outflow of the breath. This can be as minimal as two or three cycles per minute. When the respiratory rate is thus lowered, the metabolic rate of the body also reduces. All the cells are in rest and relaxed. The sympathetic overdrive is reduced, with consequent energy conservation and also helps in improving sleep [2].

Sleep is one of nature's greatest invention and blessings of life. It is a periodic rest of the body which is absolutely essential for its efficient functioning. It has been called "most cheering restorative of tired bodies". Sleep is the indispensable condition to the recuperation of energy. We go to bad fatigue and get up refreshed. Sleep repairs the wear and tear of the body and mind incurred during waking hours. Nothing is so restorative to the nerves as sound and uninterrupted sleep. Sleep is thus a vital element in a total way of life. It is a basic need in man's mental as well as physical life. During sleep most of the functions of the body are carried on at the lowest level possible in health. Heat production is from $10 \%$ to $15 \%$ below the basal level. The mechanisms regulating the body temperature are less sensitive then in the waking state and are depressed by 0.5 to 1.0 degree F. The rate of heart is reducing by 10 to 30 beats per minute and a decline in blood pressure of about $20 \mathrm{~mm} / \mathrm{hg}$ occurs in quite restful sleep. The urine volume is considerably reduced but its concentration in solids is increase. The tone of all the skeletal muscle is lessened. The eyes are usually rolled upward and the pupils constricted. Loss of sleep exerts seriously detrimental effects upon the nervous system. Long period of wakefulness may cause profound psychological changes such as loss of memory, irritability, hallucination and even schezothrenic manifestations [4].

According to the principles and practice of Sleep Medicine, "Sleep is a reversible behavioral state for sustained immobility and perceptual disengagement from the environment or we can say that unresponsiveness to the environment". Sleep is typically (but not necessarily) accompanied by postural recumbence closed eyes, behavioral quiescence and other indicators one commonly related with sleeping [4]. Insomnia or Sleeplessness has assumed alarming proportions in present time. This is evident from the wide range of medication for this condition described by physicians and sold by chemist. Insomnia deprives a person of mental rest and thereby interferes with his activities in the daytime. It constitutes severe health hazard when it become a habit.

\section{Objectives of the Study}

a. To determine insomnia rating scale after normal training (not very high intensity or volume) for duration of one month till the competition of female judo players age ranging from 17 to 23 years.

b. To find out the effect of yogic training program on insomnia rating scale just two or three days before the competition of female judo players age ranging from 17 to 23 years.

\section{Delimitations of the Study}

The study was delimited to sixty female judo players age ranging from 17 to 23 years. Sleep quality index will be studied using Pittsburgh Insomnia Rating Scale Hindi translation/ adaptation i.e. PIRS-Hindi.

\section{Hypotheses of the Study}

a. It was hypothesized that there will be negative effect on insomnia rating scale just two or three days before the competition of female judo players age ranging from 17 to 23 years.

b. It was hypothesized that there will be positive effect of selected yogic training programme on insomnia rating scale 
just two or three days before the competition of female judo players age ranging from 17 to 23 years.

\section{Selection of Subjects and Variables}

Keeping in view the purpose of the study, a large number of female judo players were randomly selected $(\mathrm{N}=60)$ equally divided into experimental group and control group. The corresponding experimental and control group were homogeneous/matched groups in regard to age and sex. The experimental groups were treated with yogic training programme for 30 to 45 minutes progressively, for six days per week, for six weeks, whereas the control groups were not given any treatment. The selected variables were distress score (DS), sleep parameter (SP), quality of life (QL) and total score (TOT).

\section{Administration of Tests and Collection of Data}

a) PIRS-Hindi was administered (after determining it's scientific authenticity) to determine the insomnia rating scale after normal training of female judo players age ranged from 17 Table 1: Time allocation for different phases of training.

\begin{tabular}{|c|c|c|}
\hline Duration & Phase & Training Components \\
\hline 10 minutes & Preparatory Phase & $\begin{array}{c}\text { Attendance Body Stretch-upwards and sideward, Neck } \\
\text { Exercise, Shoulder Rotations, Hamstring and Quadriceps } \\
\text { Stretches, Hip Circumduction, Five Deep Breathing, Five Om } \\
\text { Recitations }\end{array}$ \\
\hline $\begin{array}{c}\text { Initially fixed for } 30 \text { minutes } \\
\text { depending upon the adaptations, } \\
\text { session was increased to } 45 \text { minutes }\end{array}$ & Main Phase & Anulom-Vilom Pranayama Om Chanting \\
\hline 10 minutes & Final Phase & Shavasana, Feedback/conclusions \\
\hline
\end{tabular}

\section{Statistical Analysis of Data}

Following statistical techniques were administered:

a) Descriptive Statistics (Mean and Standard Deviation)

b) Analysis of Variance

Table 2: Descriptive statistics of PIRS.

\begin{tabular}{|c|c|c|c|c|c|}
\hline S.No & Variables & EPRT Mean+SD & EPOT Mean+SD & CPRT Mean+SD & CPOT Mean+SD \\
\hline 1 & DS & $42.000+7,497$ & $36.633+9,0686$ & $43.500+6.877$ & $67.667+10.742$ \\
\hline 2 & SP & $7.667+1.322$ & $5,900+1.826$ & $7.733+1.285$ & $9.667+0.884$ \\
\hline 3 & QL & $5.433+1.888$ & $8.700+1.317$ & $5.800+1.827$ & $8.933+1.172$ \\
\hline 4 & GS & $55.100+7.508$ & $51.233+9.964$ & $57.033+7.402$ & $86.267+10.815$ \\
\hline
\end{tabular}

Note: EPRT: Experimental Group Pre test (N1=30).

EPOT: Experimental Group Post Test (N2=30).

CPRT: Control Group Pre Test (N3=30).

CPOT: Control Group Post Test (N4=30).

SD: Standard Deviation.
The drawn hypothesis was tested at 0.05 level of significance. Findings of the Study

(Table 2) The descriptive statistics of PIRS have been graphically illustrated in (Figure 1-4) (Table 3 \& 4) ears to 23 years.

the insomnia rating scale just two or three days before the competition of female judo players age ranged from 17 years to 23 years

c) Experimental group and control group were selected randomly and were administered with PIRS-Hindi as pretest and there after the experimental groups was administered with ed yogic training programme after six weeks of training determine the insomnia rating scale of both the groups i.e. control group and experimental group then both the groups group as well as between the groups

(Table 1) were compared between pretest and post test score of each 
Table 3: Analysis of variance of PIRS.

\begin{tabular}{|c|c|c|c|c|c|c|}
\hline Variables & & Sum of Squares & Df & Mean Square & $\mathbf{F}$ & Sig. \\
\hline \multirow[t]{3}{*}{ DS } & Between groups & 17130.567 & 3 & 5710.189 & 75.847 & .000 \\
\hline & Within groups & 8733.133 & 116 & 75.286 & & \\
\hline & Total & 25863.7 & 119 & & & \\
\hline \multirow[t]{3}{*}{ SP } & Between groups & 213.092 & 3 & 71.031 & 37.813 & .000 \\
\hline & Within groups & 217.9 & 116 & 1.878 & & \\
\hline & Total & 430.992 & 119 & & & \\
\hline \multirow[t]{3}{*}{$\mathrm{QL}$} & Between groups & 310.033 & 3 & 103.344 & 41.29 & .000 \\
\hline & Within groups & 290.333 & 116 & 2.503 & & \\
\hline & Total & 600.367 & 119 & & & \\
\hline \multirow[t]{3}{*}{ TOT } & Between groups & 23292.092 & 3 & 7764.031 & 94.854 & .000 \\
\hline & Within groups & 9494.9 & 116 & 81.853 & & \\
\hline & & 32786.992 & 119 & & & \\
\hline
\end{tabular}

\section{$\mathrm{N} 1+\mathrm{N} 2+\mathrm{N} 3+\mathrm{N} 4=\mathrm{N}=120$}

Table 4: Post hoc tests of PIRS.

\begin{tabular}{|c|c|c|c|c|c|c|c|}
\hline Variable & \multicolumn{4}{|c|}{ Group } & \multirow[t]{2}{*}{ Mean Difference } & \multirow[t]{2}{*}{ Std. Error } & \multirow[t]{2}{*}{ Sig } \\
\hline \multirow{6}{*}{ DS } & 1 & 2 & 3 & 4 & & & \\
\hline & 1 & 2 & & & $5.367^{*}$ & 2.24 & 0.018 \\
\hline & 1 & & 3 & & -1.5 & 2.24 & 0,504 \\
\hline & 1 & & & 4 & $-25.667^{*}$ & 2.24 & 0 \\
\hline & & 2 & & 4 & $-31.033^{*}$ & 2.24 & 0 \\
\hline & & & 3 & 4 & $-24.167^{*}$ & 2.24 & 0 \\
\hline \multirow{5}{*}{ SP } & 1 & 2 & & & $1.767^{*}$ & 0.354 & 0 \\
\hline & 1 & & 3 & & -0.067 & 0.354 & 0.851 \\
\hline & 1 & & & 4 & $-2.000^{*}$ & 0.354 & 0 \\
\hline & & 2 & & 4 & $-3.767 *$ & 0.354 & 0 \\
\hline & & & 3 & 4 & $-1.933^{*}$ & 0.354 & 0 \\
\hline \multirow{5}{*}{ QL } & 1 & 2 & & & $-3.267^{*}$ & 0.408 & 0 \\
\hline & 1 & & 3 & & -0.367 & 0.408 & 0.371 \\
\hline & 1 & & & 4 & $-3.500 *$ & 0.408 & 0 \\
\hline & & 2 & & 4 & $-0.233^{*}$ & 0.408 & 0.567 \\
\hline & & & 3 & 4 & $-3.133^{*}$ & 0.408 & 0 \\
\hline \multirow{5}{*}{ TOT } & 1 & 2 & & & $3.867^{*}$ & 2.336 & 0.101 \\
\hline & 1 & & 3 & & -1.933(N.S.) & 2.336 & 0.41 \\
\hline & 1 & & & 4 & $-31.167^{*}$ & 2.336 & 0 \\
\hline & & 2 & & 4 & $-35.033^{*}$ & 2.336 & 0 \\
\hline & & & 3 & 4 & $-29.233^{*}$ & 2.336 & 0 \\
\hline
\end{tabular}

Note: N=120; 1=Experimental Pretest Group, 2=Experimental Post Test Group, 3=Control Pretest Group, 4=Control Post Test Group. *The mean difference is significant at the 0.05 level.

N.S.= Not significant at 0.05 level. 


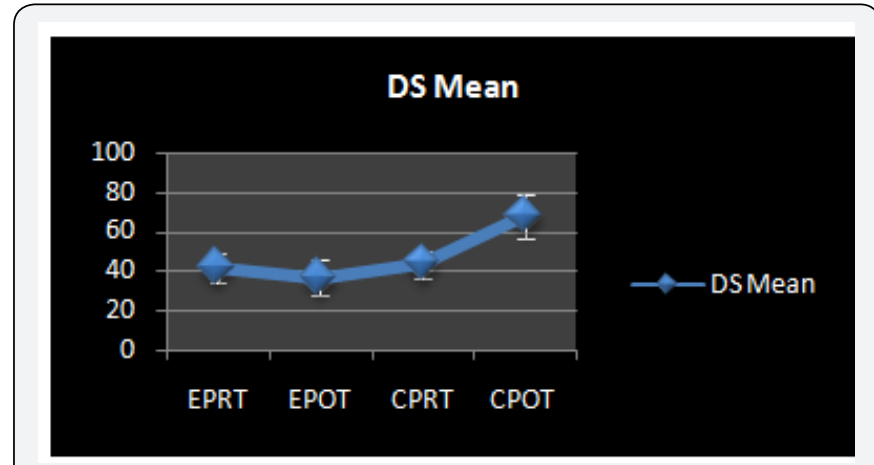

Figure 1: Mean+SD of distress score (PIRS).

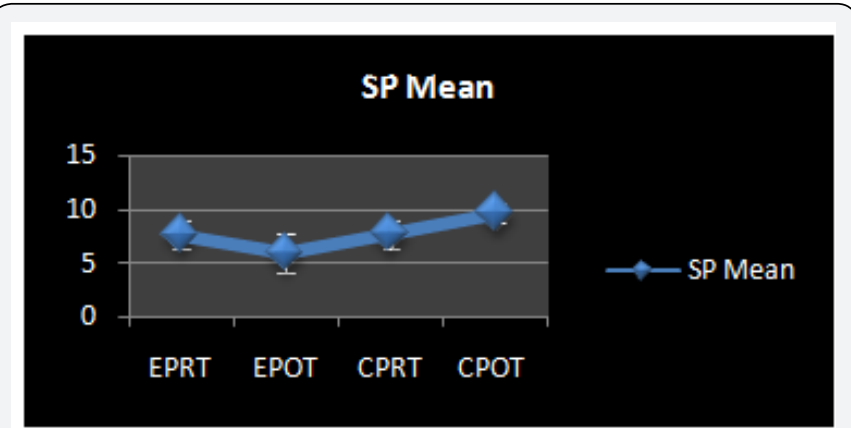

Figure 2: Mean+SD of sleep parameter (PIRS).
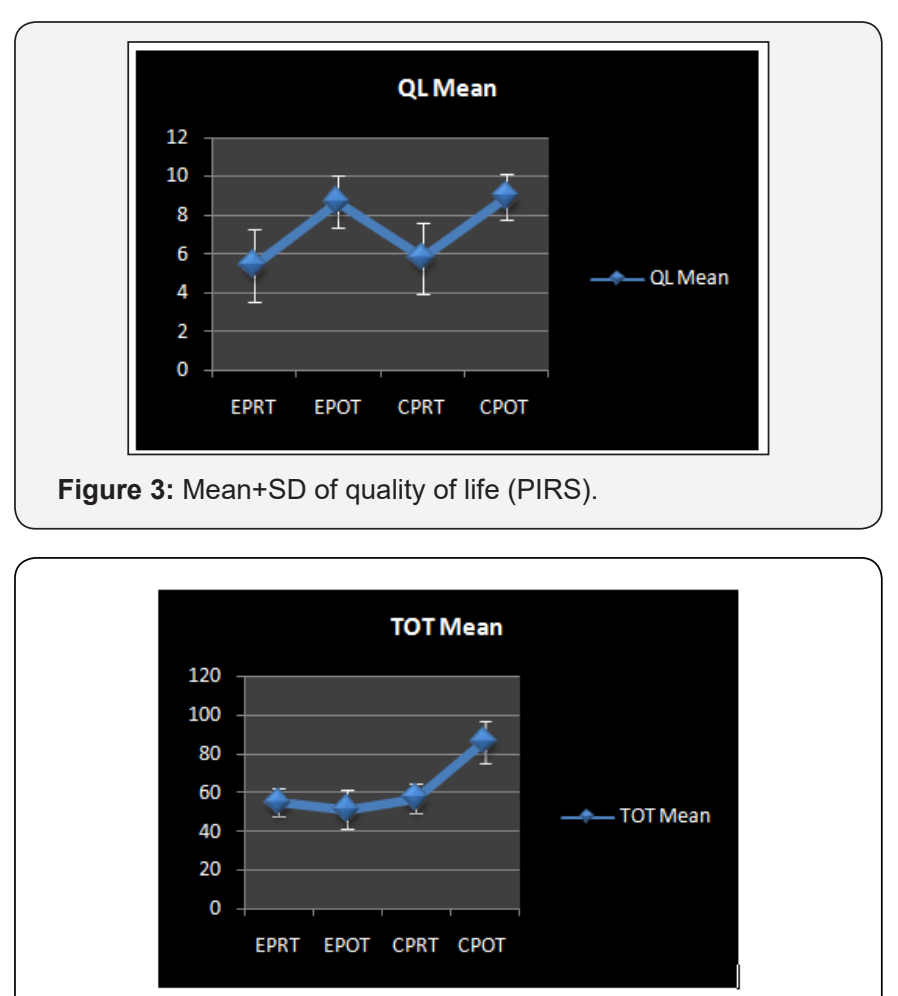

Figure 4: Mean+SD of total score

\section{Discussion of Findings}

In Post Hoc Analysis (LSD Multiple Comparisons) of Hindi Version of PIRS (sixty five items), in regard to variables namely
DS, SP, QL and TOT, experimental pre test group and control pre test group were homogeneous, experimental post test group and control post test group were significantly different which means judo competition less negative effect on the experimental group due to yogic training programme as compared with control group and control pre test group and control post test group were significantly different, showed the negative effect of judo competition.

There are many researches which shows the effect of physical training or exercise on sleep [5-10]. Such analysis was created a baseline data to understand the research outcomes. Many researches were done which shows the negative effect of competition on the mental health, physical health and sleep of sports persons. Many researches were done which shows the positive effect of yogic training programme on the mental health, physical health and sleep of sports persons [11-28].

\section{Conclusion}

A. The findings have been comprehensively and critically appraised to draw the following conclusions.

B. Experimental group and control group were not significantly different in pretest in regard to selected variables of insomnia rating scale hence considered as homogeneous group for experimentation.

C. There was negative effect of judo competition on insomnia rating scale (just two or three days) before the judo competition

D. There was significant difference between the experimental group (trained with selected yogic training programme) and control group (not trained with selected yogic training programme) just two or three days before the competition in regard to selected variables of insomnia rating scale.

E. There was significant positive effect of yogic training programme on insomnia rating scale just two or three days before the competition of female judo players age ranged from 17 to 23 years.

\section{References}

1. Ramdev S (2015) Patanjali Yog Peeth (UK) Trust.

2. Iyengar BKS (2001) Light on Yoga. Thornsons, London.

3. Iyengar BKS (2002) Light on the Sutras of Patanjali. Thornsons/ Harper, London.

4. Carskadon MA, Dement WC (2010) Normal Human Sleep-an overview. In: MH Kryger, T Roth, WC Dement (Eds.), Principles and Practice of Sleep Medicine ( $5^{\text {th }}$ edn), St. Louis, Saunders, Missouri, USA.

5. Kubitz KA, Landers DM, Petruzzello SJ, Han M (1996) The effects of acute and chronic exercise on sleep A meta-analytic review. Sports Med 21(4): 277-291. 


\section{Journal of Yoga and Physiotherapy}

6. North TC, McCullagh P, Tran ZV (1990) Effect of Exercise on Depression Exerc Sport Sci Rev 18: 379-415.

7. Chen X, Beydoun MA, Wang Y (2008) Is sleep duration associated with childhood obesity? A Systematic Review and Meta-Analysis. Obesity (Silver Spring) 16(2): 265-274.

8. Fox KR (1999) The influence of physical activity on mental well-being. Public Health Nutr 2(3A): 411-418.

9. Nelson ME, Rejeski WJ, Blair SN, Duncan PW, Judge JO, et al. (2007) Physical activity and public health in older adults: recommendation from the American College of Sports Medicine and the American Heart Association. Med Sci Sports Exerc 116(9): 1091-1105.

10. Ancoli Israel S, Cole R, Alessi C, Chambers M, Moorcroft W, et al. (2003) The role of actigraphy in the study of sleep and circadian rhythms. Sleep 26(3): 342-392.

11. Raub JA (2002) Psychophysiologic effects of hatha yoga on musculoskeletal and cardiopulmonary function: a literature review. Altern Complement Med 8(6): 797-812.

12. Wells C, Kolt GS, Bialocerkowski A (2012) Defining Pilates exercise: a systematic review. Complement Ther Med 20(4): 253-256.

13. Hurel SJ, Koppiker N, Newkirk J, Close PR, Miller M, et al. (1999) Relationship of physical exercise and ageing to growth hormone production. Clin Endocrinol (Oxf) 51(6): 687-691.

14. Caldwell K, Harrison M, Adams M, Quin RH, Greeson J (2010) Developing mindfulness in college students through movement-based courses: effects on self-regulatory self-efficacy, mood, stress, and sleep quality. J Am Coll Health 58(5): 433-442.

15. (2001) AASM, The International Classification of Sleep Disorders (ICSD), Revised. diagnostic and coding manual Chicago, Ill: American Academy of sleep medicine.

16. Aloba 00, Adewuya AO, Ola BA, Mapayi BM (2007) Validity of the Pittsburgh Sleep Quality Index (PSQI) among Nigerian university students. Sleep Med 8(3): 266-270.

17. Joseph B, Jeane C, Bruce A (2003) Sport-Specific Practice and the development of expert decision-making in team ball sports. Journal of Applied Sport Psychology 15(1): 12-25.
18. Rast SD, Hojjati Z, Shabani R (2013) The Effect of yoga training on lipid profile and blood glucose in type II diabetic females. Annals of Biological Research 4(8): 128-133.

19. Cohen L, Warneke C, Fouladi RT, Rodriguez AM, Chaoul Reice A (2004) Psychological adjustment and sleep quality in a randomized trial of the effects of a Tibetan yoga intervention in patients with lymphoma. Cancer 100(10): 2253-2260.

20. Burkhalter H, Sereika Susan M, Engberg, Sandra E, Wirz Justice A, Steiger J, et al. (2010) Structure validity of the pittsburgh sleep quality index in renal transplant recipients: a confirmatory factor analysis. Sleep and Biological Rhythms 8(4): 274-281.

21. Caldwell K, Harrison M, Adams M, Quin RH, Greeson J (2010) Developing mindfulness in college students through movement-based courses: effects on self-regulatory self-efficacy, mood, stress, and sleep quality. J Am Coll Health 58(5): 433-442.

22. Carson JW, Carson KM, Porter LS, Keefe FJ, Shaw H, et al. (2007) Yoga for women with metastatic breast cancer: results from a pilot study. J Pain Symptom Manage 33(3): 331-341.

23. Giuseppe C, Daniela T, Simone S, Cristina M, Chandrashekhar R, et al. (2012) A Healthy way to handle work place stress through Yoga, Meditation and Soothing humor. International Journal of Environmental Sciences 2(4): 2143- 2154.

24. Pal GK, Agarwal A, Karthik S, Pal P, Nanda N (2014) Slow yogic breathing through right and left nostril influences sympathovagal balance, heart rate variability and cardiovascular risks in young adults. $\mathrm{N}$ Am J Med Sci 6(3): 145-151.

25. Iyengar BKS (2009) Yoga wisdom and practice. Dorling Kindersley, London, p. 256

26. Raub JA (2002) Psychophysiologic effects of hatha yoga on musculoskeletal and cardiopulmonary function: a literature review. J Altern Complement Med 8(6): 797-812.

27. Shochat T, Tzischinsky O, Oksenberg A, Peled R (2007) Validation of the Pittsburgh sleep quality index hebrew translation (PSQI-H) in a sleep clinic sample. Isr Med Assoc J 9(12): 853-856.

28. Khalaila R (2013) Translation of questionnaires into arabic in crosscultural research: techniques and equivalence issues. J Transcult Nurs 24(4): 363-370.

\section{Your next submission with Juniper Publishers will reach you the below assets}

- Quality Editorial service

- Swift Peer Review

- Reprints availability

- E-prints Service

- Manuscript Podcast for convenient understanding

- Global attainment for your research

- Manuscript accessibility in different formats

( Pdf, E-pub, Full Text, Audio)

- Unceasing customer service

Track the below URL for one-step submission https://juniperpublishers.com/online-submission.php 